\title{
MiR-375 Regulation of LDHB Plays Distinct Roles in Polyomavirus-Positive and -Negative Merkel Cell Carcinoma
}

\author{
Satendra Kumar ${ }^{1,2, \dagger}$, Hong Xie ${ }^{1,2,3,+} \oplus$, Patrick Scicluna ${ }^{1,2,4}$, Linkiat Lee ${ }^{1,2}$, \\ Viveca Björnhagen ${ }^{5}$, Anders Höög ${ }^{1,2,6}\left(\mathbb{D}\right.$, Catharina Larsson ${ }^{1,2,6}$ and Weng-Onn Lui $1,2, *(\mathbb{D})$ \\ 1 Department of Oncology-Pathology, Karolinska Institutet, SE-17176 Stockholm, Sweden; \\ satendra.kumar@ki.se (S.K.); xiehong@tmu.edu.cn (H.X.); patrick.scicluna@ki.se (P.S.); \\ Linkiatlee@gmail.com (L.L.); anders.hoog@ki.se (A.H.); catharina.larsson@ki.se (C.L.) \\ 2 Cancer Center Karolinska, Karolinska University Hospital, SE-17176 Stockholm, Sweden \\ 3 Tianjin Life Science Research Center and Department of Pathogen Biology, School of Basic Medical Sciences, \\ Tianjin Medical University, Tianjin 300070, China \\ 4 Department of Cell and Molecular Biology, Karolinska Institutet, SE-17165 Stockholm, Sweden \\ 5 Department of Reconstructive Plastic Surgery, Karolinska University Hospital, SE-17176 Stockholm, Sweden; \\ viveca.bjornhagen-safwenberg@sll.se \\ 6 Department of Clinical Pathology and Cytology, Karolinska University Hospital, \\ SE-17176 Stockholm, Sweden \\ * Correspondence: weng-onn.lui@ki.se; Tel.: +46-8-517-73930 \\ + These authors contributed equally to this work.
}

Received: 19 October 2018; Accepted: 12 November 2018; Published: 14 November 2018

check for updates

\begin{abstract}
MicroRNA-375 (miR-375) is deregulated in multiple tumor types and regulates important targets involved in tumorigenesis and metastasis. This miRNA is highly expressed in Merkel cell carcinoma (MCC) compared to normal skin and other non-MCC skin cancers, and its expression is high in Merkel cell polyomavirus (MCPyV)-positive (MCPyV+) and low in $\mathrm{MCPyV}$-negative $(\mathrm{MCPyV}-) \mathrm{MCC}$ tumors. In this study, we characterized the function and target of miR-375 in $\mathrm{MCPyV}+$ and MCPyV - MCC cell lines. Ectopic expression of miR-375 in MCPyV- MCC cells resulted in decreased cell proliferation and migration, as well as increased cell apoptosis and cell cycle arrest. However, in MCPyV+ MCC cells, inhibition of miR-375 expression reduced cell growth and induced apoptosis. Additionally, the expression of lactate dehydrogenase $\mathrm{B}(\mathrm{LDHB})$, a known target of $m i R-375$, was inversely correlated with $m i R-375$. Silencing of LDHB reduced cell growth in $\mathrm{MCPyV}$ - cell lines, while its silencing in $\mathrm{MCPyV}+$ cell lines rescued the cell growth effect mediated by $m i R-375$ inhibition. Together, our results suggest dual roles of $m i R-375$ and LDHB in MCPyV and non-MCPyV-associated MCCs. We propose that LDHB could be a therapeutic target in MCC and different strategies should be applied in virus- and non-virus-associated MCCs.
\end{abstract}

Keywords: Merkel cell carcinoma; Merkel cell polyomavirus; miR-375; LDHB; cell growth

\section{Introduction}

Merkel cell carcinoma (MCC) is a highly aggressive form of neuroendocrine cancer of the skin. The majority of cases are caused by the Merkel cell polyomavirus (MCPyV) [1] that was found monoclonally integrated into cancer cell genome with tumor-specific $\mathrm{T}$ antigen mutations of importance for MCC tumorigenesis [2-12]. Besides, $20 \%$ of MCC tumors do not have detectable $\mathrm{MCPyV}$, indicating different etiologies and clinical outcomes between MCPyV-positive $(\mathrm{MCPyV}+)$ and $\mathrm{MCPyV}$-negative $(\mathrm{MCPyV}-) \mathrm{MCC}$ tumors. In line with this distinction, we and others have 
reported different clinical and molecular features between MCPyV+ and MCPyV- MCCs [13-18]. In our previous study, we identified a subset of differentially expressed microRNAs (miRNAs) between $\mathrm{MCPyV}+$ and MCPyV - MCC tumors [18]. Among them, microRNA-375 (miR-375) expression was found to be significantly higher in the MCPyV+ than the MCPyV- MCC tumors. Importantly this miRNA is highly specific to MCC compared to non-MCC tumors and cell lines [19,20]; its expression is also higher in serum samples of MCC patients than tumor-free patients or healthy individuals, suggesting its potential use as a surrogate marker for tumor burden in MCC [19].

Deregulation of miR-375 expression has been reported in multiple types of cancer. Typically, miR-375 is under-expressed such as in gastric carcinoma [21,22], glioma [23], colon cancer [24,25], head and neck squamous cell carcinoma [26], pancreatic cancer [27], hepatocellular carcinoma [28], and squamous cervical cancer [29]. However, overexpression of miR-375 has also been observed in medullary thyroid carcinoma [30], breast cancer [31], and prostate cancer [32].

Functionally, miR-375 acts as a tumor suppressor that inhibits cell proliferation, migration, invasion, and tumor metastasis $[21,28,29,33]$ by targeting several important oncogenes, including phosphoinositide-dependent protein kinase-1 (PDK1) [22,34], 14-3-3 protein zeta (14-3-3乙) [22,35], Yes-associated protein (YAP) [36], astrocyte elevated gene-1 (AEG1) [28,37,38], lactate dehydrogenase B (LDHB) [39], and Janus kinase 2 (JAK2) [21]. On the other hand, an oncogenic role of $m i R-375$ has been demonstrated in prostate and breast cancers. In prostate cancer, miR-375 is highly expressed in high-grade and metastatic tumors, and its over-expression increases cell growth [40], while in breast cancer, its inhibition led to decreased cell growth [31]. In MCC, ectopic expression of miR-375 in $\mathrm{MCPyV}-\mathrm{MCC}$ cell lines was found to promote neuroendocrine differentiation and exhibit tumor suppressor effects [41]. However, its functional role in MCPyV+ MCCs is yet to be determined.

Among the miR-375 targets, LDHB was found upregulated in MCC tumors compared to carcinoid tumors of the lung, based on a proteomic approach [42]. LDHB is a key enzyme that catalyzes the conversion of lactate to pyruvate and NAD+ to NADH (an oxidized and reduced form of nicotinamide adenine dinucleotide, respectively) and is known to play important roles in cancer cell growth and progression [43-45]. Similar to the dual roles of $m i R-375$, LDHB has also been demonstrated to enhance or suppress tumorigenesis depending on the cellular context $[43,44]$. Although LDHB was detected in some MCC tumors [42], its functional role in MCC remains unknown.

In this study, we investigated the relation between expression of miR-375 and LDHB, and their functional roles in MCC. We observed that LDHB expression was inversely correlated with $m i R-375$ levels. Interestingly, LDHB was found to have distinct roles in MCPyV+ and MCPyV-MCC cells.

\section{Results}

\section{1. miR-375 and LDHB Expression Levels Are Inversely Correlated in MCC}

To evaluate whether LDHB could be a potential target of miR-375 in MCC, we quantified miR-375 and LDHB expressions in three MCPyV - (MCC13, MCC14/2, and MCC26) and MCPyV+ (MKL-1, MKL-2 and WaGa) MCC cell lines using RT-qPCR and Western blotting, respectively. miR-375 levels were higher in all three MCPyV+ than the MCPyV - cell lines, whereas the LDHB levels were opposite (Figure 1A,B). To further establish the expression relationship between miR-375 and LDHB, we compared miR-375 and LDHB mRNA expressions in a series of 54 MCC tumor samples. Consistent with the observation in cell lines, miR-375 was inversely correlated with $L D H B$ mRNA levels ( $p<0.0001$, Spearman's rank order correlation, Figure 1C). 
A

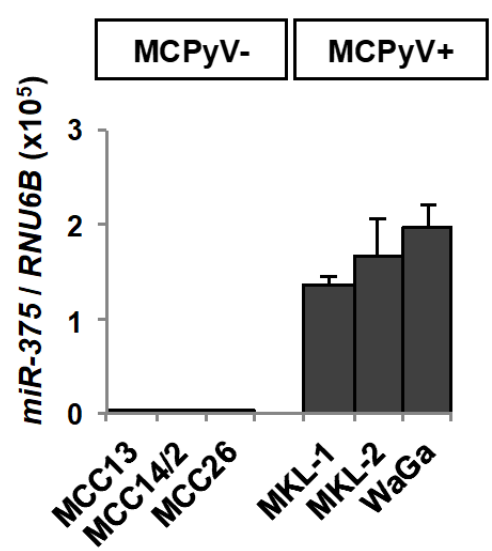

B
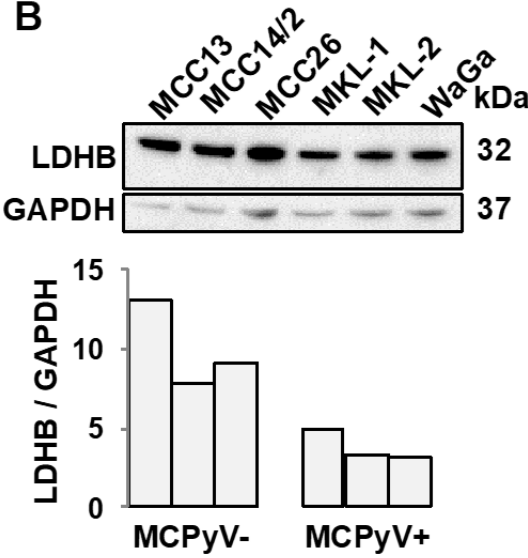

C

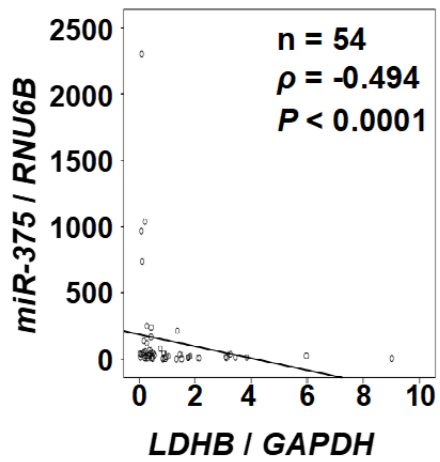

Figure 1. LDHB is inversely correlated with $m i R-375$ in MCC tumors and cell lines. (A) $m i R-375$ levels were quantified in six MCC cell lines using RT-qPCR. RNU6B was used for normalization purpose. Error bars represent SEM of four independent RNA isolations and RT-qPCR measurements. (B) Western blot analysis of LDHB protein expression in MCC cell lines. Western blot images of the LDHB and GAPDH levels are shown in the upper panel, and the quantifications of the LDHB levels are presented in the graph. The LDHB levels were normalized to GAPDH. (C) miR-375 and LDHB mRNA levels were measured in 54 MCC tumor samples using RT-qPCR. The expression correlation between miR-375 and LDHB mRNA was assessed by Spearman's rank order correlation.

\section{2. miR-375 Regulates LDHB Expression in MCC Cells}

We next assessed whether miR-375 could regulate LDHB expression in MCC cell lines. We ectopically expressed miR-375 using an expression plasmid (miR-375 OE) in the three MCPyV - cell lines and silenced miR-375 using miRNA sponge (miR-375sp) in two MCPyV+ cell lines. Transfection with miR-375 OE increased miR-375 levels in all three MCPyV - cell lines, while inhibition of miR-375 (miR-375sp) reduced its levels in both WaGa and MKL-1 cells (Figure 2A). Furthermore, miR-375 over-expression reduced and its inhibition increased LDHB mRNA and protein levels (Figure 2B,C). Taken together, these observations indicate that LDHB is a target of miR-375 in MCC.

Given that miR-375 is one of the MCC-specific miRNAs and its differential expression between $\mathrm{MCPyV}+$ and MCPyV-MCC tumors, we sought to determine whether miR-375 plays distinct roles in these two tumor entities.

\subsection{Over-Expression of miR-375 Inhibits Cell Growth and Migration in MCPyV-MCC Cell Lines}

To determine the effect of miR-375 on tumor phenotypes, we ectopically expressed miR-375 in the MCPyV - cell lines using miRNA mimic or expression plasmid and investigated its effect on cell growth, cell cycle, cell migration, and apoptosis. Using RT-qPCR, we validated increased miR-375 levels in cells transfected with miR-375 mimic or expression plasmid (miR-375 OE) (Figure 3A). Using WST-1 assay, we observed a decrease of cell growth after $48 \mathrm{~h}$ (MCC 14/2) or $72 \mathrm{~h}$ (MCC13 and MCC26) of transfection of miR-375 mimic (Figure 3B). Similar to the effect with miR-375 mimic, MCC14/2 cells stably transfected with miR-375 OE reduced cell growth after $48 \mathrm{~h}$, as evaluated by WST- 1 and trypan blue exclusion assays (Figure $3 \mathrm{C}$ ). The results support similar effect in miR-375 over-expressing cells using either miR-375 mimic or expression plasmid. 
A
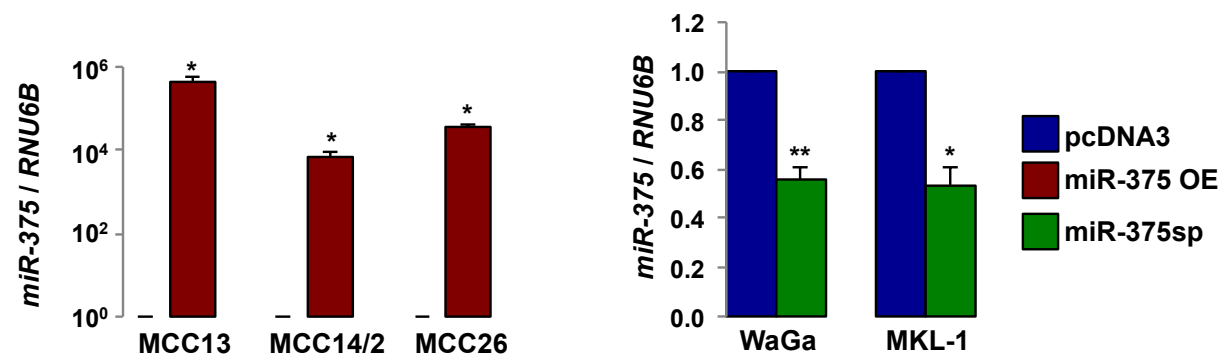

B

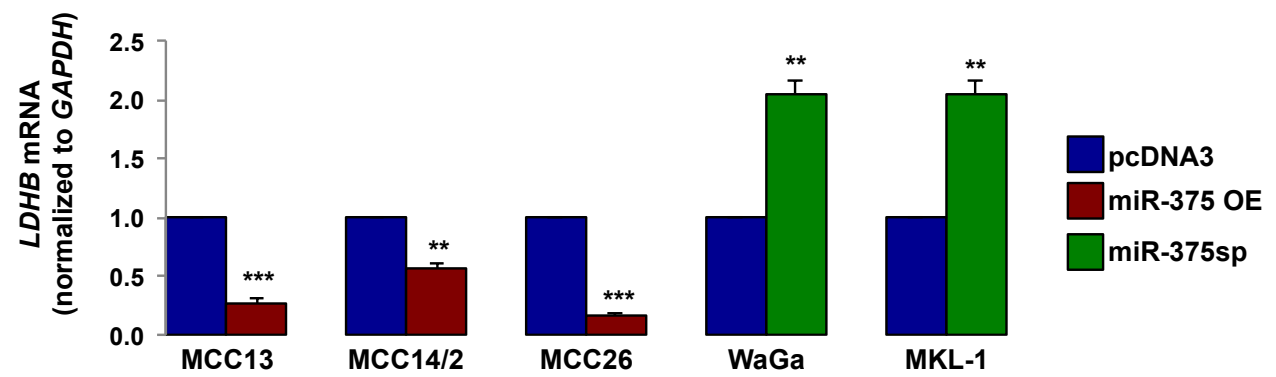

C

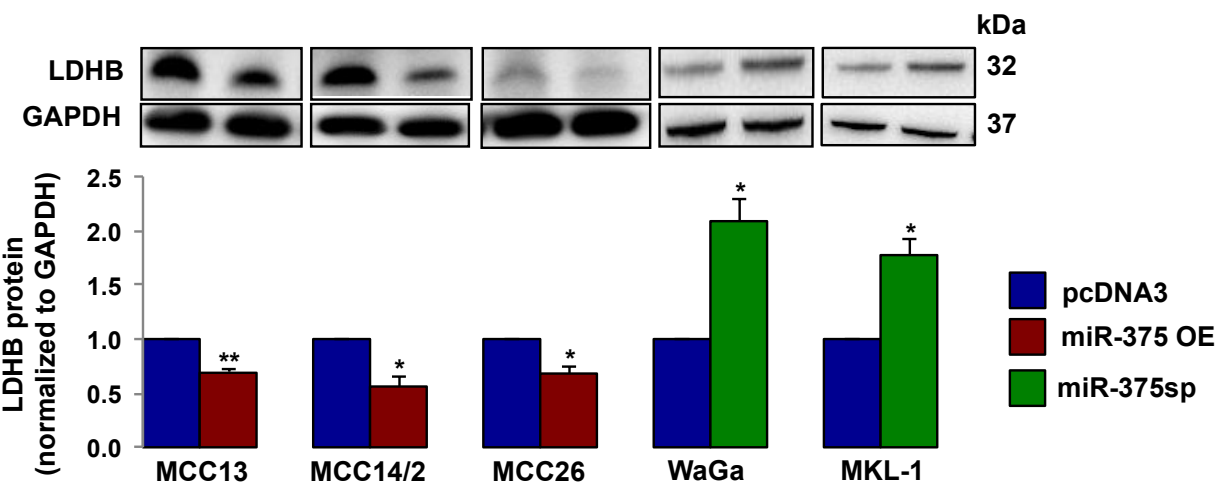

Figure 2. $m i R-375$ regulates LDHB mRNA and protein levels. (A) RT-qPCR analysis of $m i R-375$ levels in MCPyV- MCC cell lines (MCC13, MCC14/2, and MCC26) transfected with miR-375 expression plasmid (miR-375 OE) or vector control (pcDNA3) after $48 \mathrm{~h}$ of transfection and in MCPyV+ MCC cell lines (WaGa and MKL-1) transfected with miR-375 sponge (miR-375sp) or vector control (pcDNA3) after $72 \mathrm{~h}$ of transfection. The relative expression of miR-375 was normalized to RNU6B. (B) Quantification of $L D H B$ mRNA expressions in cells with over-expression or inhibition of miR-375 in MCC cell lines by RT-qPCR. $L D H B$ levels were normalized to GAPDH mRNA. (C) Western blot analysis of LDHB protein levels in cells with over-expression or inhibition of $m i R-375$. Representative Western blot images are shown in the upper panel, and the quantifications of LDHB levels are presented in the graph below. Error bars represent SEM $(\mathrm{n}=3){ }^{*} p<0.05,{ }^{* *} p<0.01$, and ${ }^{* * *} p<0.001$ by paired Student's $t$-test. 
A
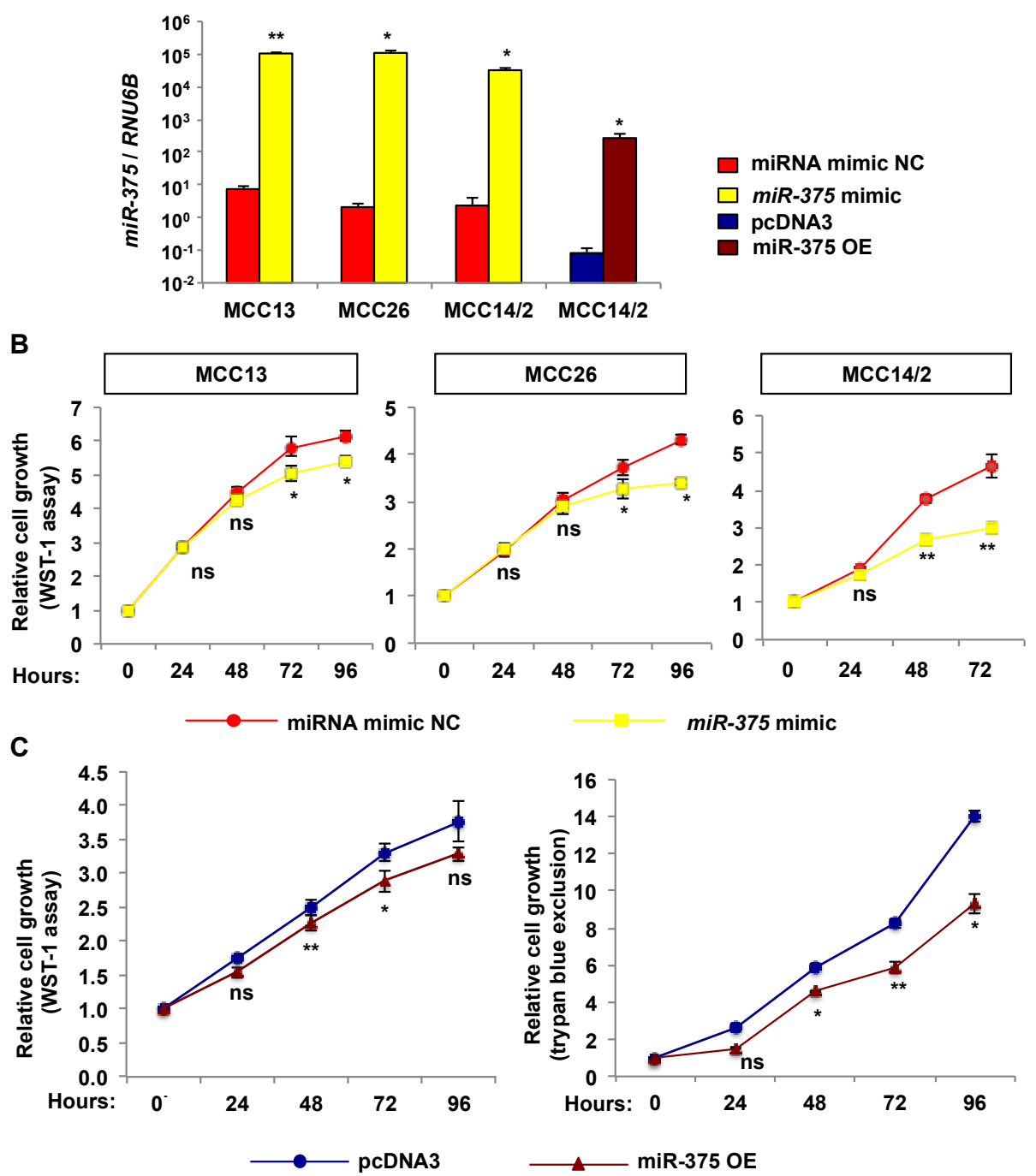

Figure 3. Over-expression of miR-375 reduces cell growth in MCPyV- MCC cell lines. MCPyVMCC cells were transfected with $m i R-375$ mimic or miR-375 OE and their respective negative controls. (A) Quantification of $m i R-375$ in the transfected cells after $48 \mathrm{~h}$ of transfection or stable miR-375 OE-transfected cells of MCC14/2 by RT-qPCR. The relative expression of miR-375 was normalized to RNU6B and compared to miRNA mimic negative control (NC) or vector control (pcDNA3). (B) Evaluation of cell growth in cells transfected with miR-375 mimic and miRNA mimic NC at different time points using WST-1 assay. (C) Cell growth in stable miR-375 OE-transfected cell line was evaluated at different time points using WST- 1 and trypan blue exclusion assays. Error bars are SEM from three independent experiments. ${ }^{*} p<0.05$ and ${ }^{* *} p<0.01$ by paired Student's $t$-test. ns $=$ not significant.

Cell cycle analysis in MCC13 and MCC14/2 revealed that miR-375 mimic-treated cells had a subtle increase (7-14\%) of cells in G1 or G2 phases compared with the negative control cells, respectively (Figure 4A). Wound healing scratch assays revealed that ectopically expressed miR-375 retarded wound closure compared with the negative control at $18 \mathrm{~h}$ or $27 \mathrm{~h}$ (Figure $4 \mathrm{~B}$ ). To determine the effect on apoptosis, we evaluated the cleavage products of Poly (ADP-ribose) polymerase (PARP) (an apoptotic marker) from cells over-expressing miR-375 or negative control using Western blot analysis. As shown in Figure 4C, we observed that the $89-\mathrm{kDa}$ cleavage product of PARP was increased in all three MCC cell lines over-expressing miR-375 compared to miRNA mimic control, suggesting that miR-375 expression induces cell apoptosis in MCPyV- MCC cells. 
A
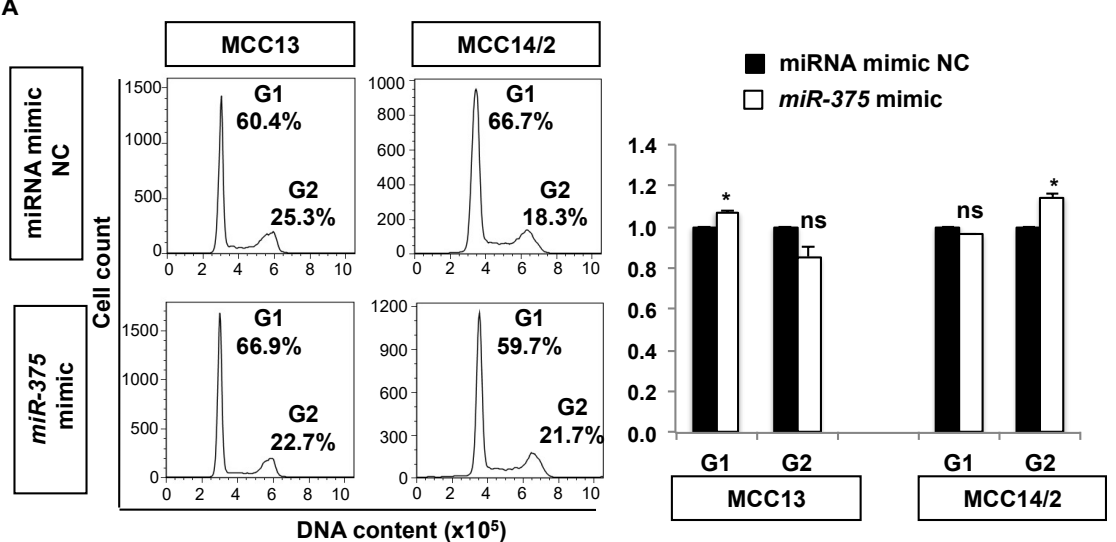

B
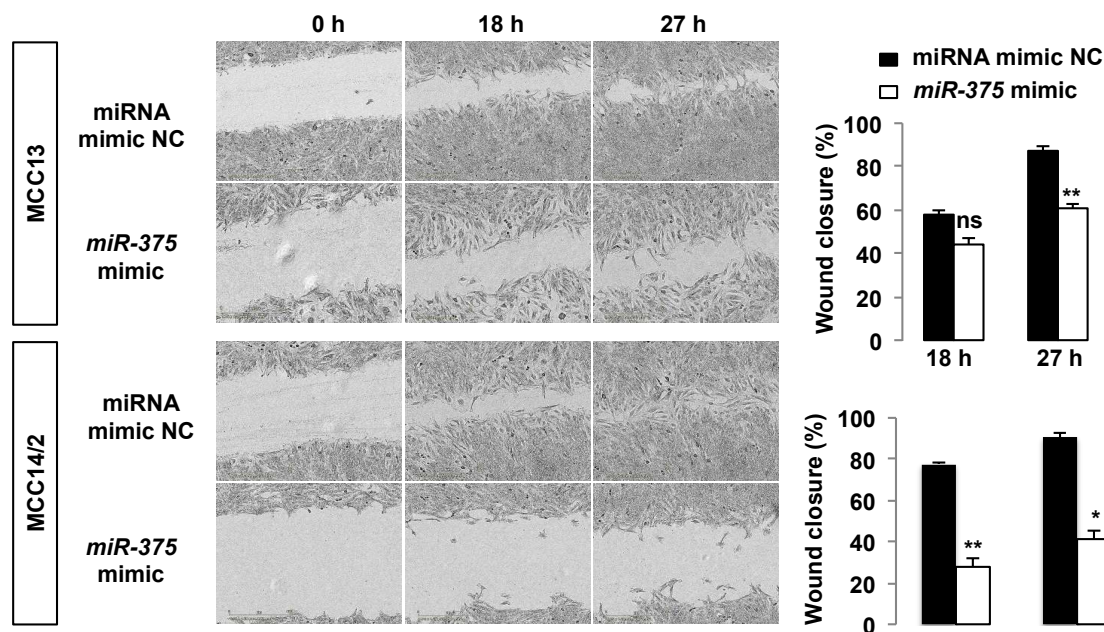

C
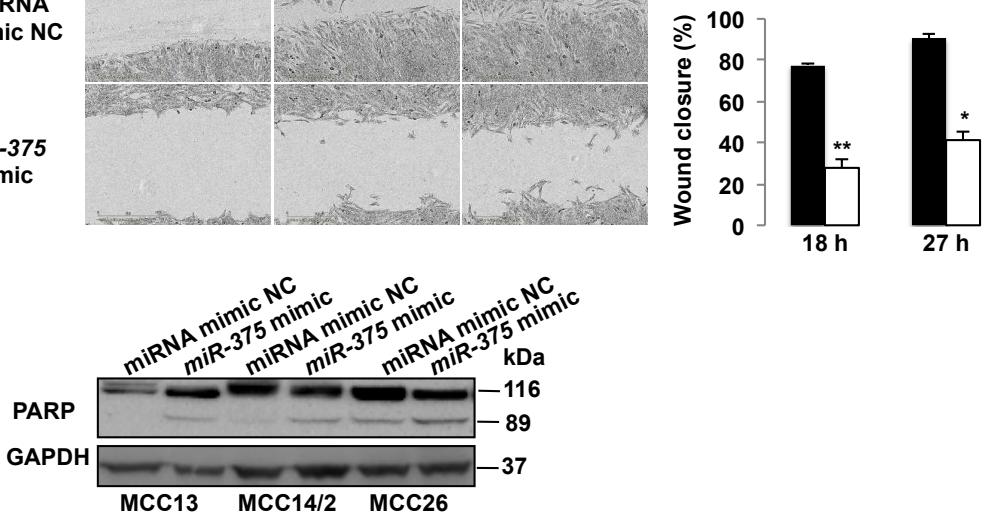

Figure 4. Over-expression of miR-375 reduces cell migration and induces cell cycle arrest and apoptosis in MCPyV - MCC cell lines. MCC13 and MCC14/2 cells were transfected with miR-375 mimic or miRNA mimic NC for $48 \mathrm{~h}$. (A) Cell cycle analysis was evaluated in transfected cells by propidium iodide staining and flow cytometric analysis. Left panel: representative histograms illustrating the percentage of cells at G1 and G2 phases in cells with and without over-expression of miR-375. Right panel: Fractions of cells at G1 and G2 phases were calculated from the histograms of three independent experiments. (B) Cell migration was evaluated using wound-healing assay. Left panel: representative images of wound closure at $18 \mathrm{~h}$ and $27 \mathrm{~h}$ time points. Right panel: the wound closure was calculated based on the difference between wound gap at $18 \mathrm{~h}$ or $27 \mathrm{~h}$ and $0 \mathrm{~h}$ time point and normalized to viable cell number of transfected cells plated in parallel. (C) Apoptosis was evaluated after $48 \mathrm{~h}$ in MCC cells transfected with miR-375 mimic or NC using Western blot analysis of anti-PARP (BD Pharmingen), which recognizes the full-length $(116 \mathrm{kDa})$ and apoptosis-associated cleaved ( $89 \mathrm{kDa})$ forms. GAPDH was used as a loading control. ${ }^{*} p<0.05$ and ${ }^{* *} p<0.01$ by paired Student's $t$-test. ns $=$ not significant.

\subsection{Inhibition of miR-375 Expression Reduces Cell Growth and Induces Apoptosis in MCPyV+MCC Cells}

We suppressed miR-375 expression in two MCPyV+ MCC cell lines using miR-375sp (Figure 5A). Using WST-1 and trypan blue exclusion assays, we observed that suppression of miR-375 led to decreased cell growth in both WaGa and MKL-1 cell lines (Figure 5B). To further examine whether 
the reduction of cell growth was due to apoptosis, we determined the apoptotic effect using Annexin $\mathrm{V}$ and caspase- 3 activity assays. For Annexin V assay, we observed that suppression of miR-375 increased the number of apoptotic cells by $13 \%(p=0.016)$ compared to the vector control-transfected cells (Figure 5C). Concordantly, we also observed increased of caspase-3 activity upon suppression of $m i R-375$ (2.7-fold, $p=0.001$; Figure 5D). Together, our results suggest that miR-375 suppression inhibited cell growth via apoptosis in MCPyV+ MCC cells.

A

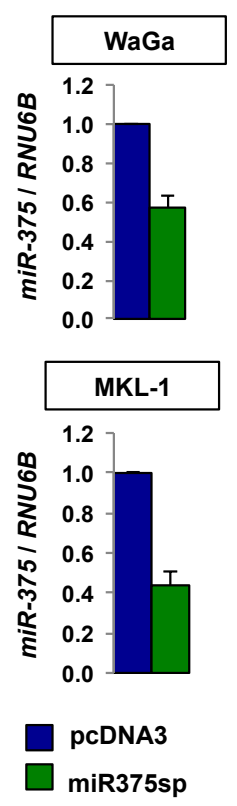

C

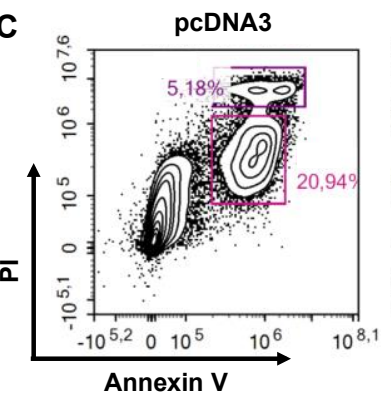

B
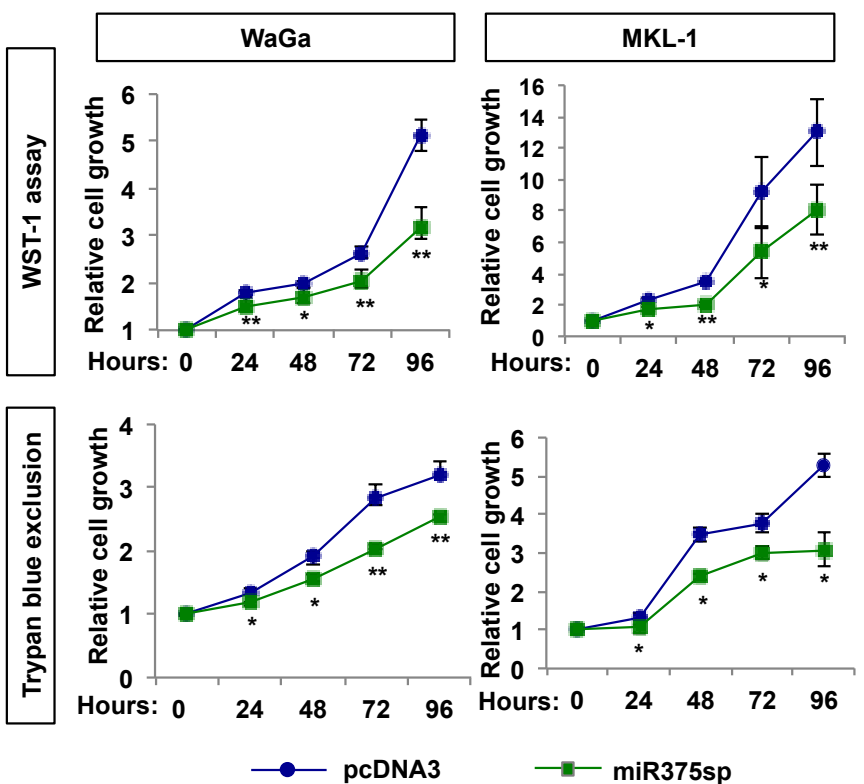

- $-\operatorname{miR} 375 \mathrm{sp}$
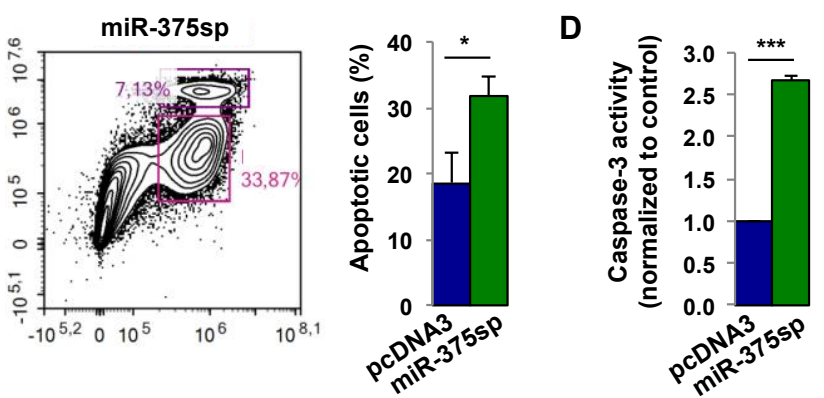

Figure 5. Inhibition of miR-375 reduces cell growth and induces apoptosis in MCPyV+ MCC cell lines. WaGa and MKL-1 cells were transfected with miR-375sp or vector control (pcDNA3) for $72 \mathrm{~h}$. (A) RT-qPCR analysis of miR-375 levels in cells transfected with miR-375sp or pcDNA3. The miR-375 expressions were normalized to RNU6B. (B) Effect of miR-375 inhibition on cell growth was evaluated at different time points using WST-1 and trypan blue exclusion assays. (C) Representative flow cytometric images of WaGa cells co-stained with Annexin V-FITC and propidium iodide (PI) upon inhibition of $m i R-375$. The apoptotic cells (Annexin $\mathrm{V}^{+} / \mathrm{PI}^{-}$) and the necrotic cells (Annexin $\mathrm{V}^{+} / \mathrm{PI}^{+}$) are represented in the lower and upper boxes, respectively. Quantification of the apoptotic cells is shown on the right panel. (D) Caspase-3 activity was quantified in WaGa cell lysates with and without inhibition of miR-375. Data are means \pm SEM of three independent experiments. ${ }^{*} p<0.05,{ }^{* *} p<0.01$, and ${ }^{* * *} p=0.001$ by paired Student's $t$-test. ns $=$ not significant.

\subsection{Silencing of LDHB Rescues Cell Growth Effect Mediated by miR-375 Suppression}

To determine whether LDHB plays a role in miR-375 regulation of cell growth, we compared cell growth in miR-375sp-transfected cells with and without silencing of LDHB using two different siRNAs (siLDHB \#1 and siLDHB \#2). In parallel, we also transfected cells with miR-375sp or vector 
control only. As shown in Figure 6A, cells transfected with miR-375sp only or together with siCTR had higher LDHB levels than the pcDNA3 vector control. Co-transfection of miR-375sp and siLDHB led to a decrease in LDHB levels compared to cells transfected with miR-375sp and siCTR. Consistently, we observed decreased cell growth upon inhibition of miR-375, in which the effect was rescued by silencing of LDHB (Figure 6B).

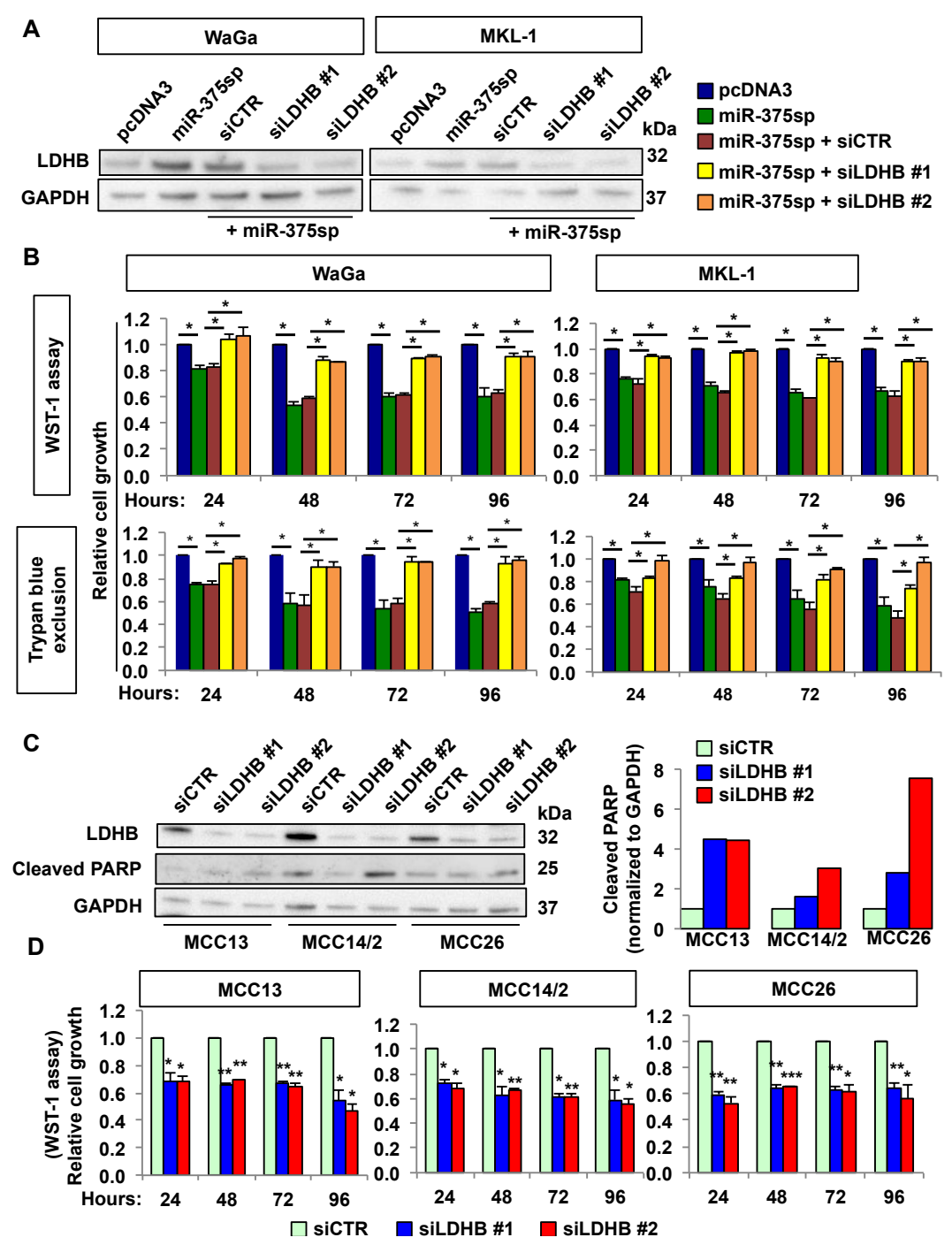

Figure 6. LDHB plays dual roles in MCPyV+ and MCPyV- MCC cells. (A,B) MCPyV+ MCC cell lines were transfected with miR-375sp or pcDNA3, or co-transfected with miR-375sp together with siCTR, siLDHB \#1, or siLDHB \#2. (A) Western blot analysis of LDHB in the transfected cells after $72 \mathrm{~h}$ of transfection. GAPDH was used as a loading control. (B) The effect on cell growth was evaluated at different time points using WST-1 and trypan blue exclusion assays. (C,D) MCPyV- MCC cell lines were transfected with siCTR, siLDHB \#1, or siLDHB \#2 for $48 \mathrm{~h}$. (C) Western blot analysis of the effect of LDHB silencing on LDHB protein level and cleaved PARP. The specific $25 \mathrm{kDa}$ cleaved form of PARP was detected using anti-cleaved PARP antibody (Abcam). Quantification of the cleaved PARP levels is presented on the right panel. (D) Effect of LDHB silencing on cell growth was evaluated using WST-1 assay. Mean $\pm \operatorname{SEM}(\mathrm{n}=3) .{ }^{*} p<0.05,{ }^{* *} p<0.01$, and ${ }^{* * *} p<0.001$ by paired Student's $t$-test.

\subsection{Silencing of LDHB Reduces Cell Growth in MCPyV-MCC Cells}

In MCPyV- MCC cells, we observed higher LDHB levels (Figure 1B) and that over-expression of $m i R-375$ reduced cell growth (Figure $3 \mathrm{~B}, \mathrm{C}$ ). We therefore asked whether silencing of LDHB could 
phenocopy the effect of miR-375 down-regulation. Indeed, silencing of LDHB reduced cell growth and increased apoptosis (as indicated by increased cleaved PARP levels) (Figure 6C,D).

\section{Discussion}

$\mathrm{MCC}$ are generally divided into $\mathrm{MCPyV}+$ and $\mathrm{MCPyV}$ - tumors, depending on their etiologies. While $\mathrm{MCPyV}$ + tumors are the most common MCCs in US and Europe, the MCPyV - tumors are more common in Australia [17,46]. Numerous data indicate anatomical, genetical, and clinical differences between $\mathrm{MCPyV}+$ and $\mathrm{MCPyV}-\mathrm{MCC}$. Anatomically, $\mathrm{MCPyV}+$ tumors are found more frequently on extremities, and MCPyV - tumors are more frequent in the head and neck [17,47]. Molecularly, $\mathrm{MCPyV}-\mathrm{MCC}$ harbor high mutation loads associated with ultra-violet (UV) signature, suggesting that UV exposure is the underlying etiology of MCPyV - MCCs [48]. On the contrary, MCPyV+ tumors have low mutation burdens, suggesting that the viral oncoproteins control key processes involved in MCC tumorigenesis [49]. Clinically, $\mathrm{MCPyV}$ - tumors are more aggressive, with increased risk of tumor progression and MCC-related death [17,47]. Additionally, MCPyV- and MCPyV+ MCCs may derive from different cell lineages [50]. All these observations support that $\mathrm{MCPyV}+$ and $\mathrm{MCPyV}-$ MCCs are distinct tumor entities.

Given substantial differences between MCPyV+ and MCPyV- MCCs, we speculated that miR-375 is functionally distinct between these two tumor types. Indeed, our results support that miR-375 acts as a tumor suppressor in $\mathrm{MCPyV}$ - and function as an oncogene in $\mathrm{MCPyV}+\mathrm{MCC}$ cell lines. Consistent with our findings, low expression of $m i R-375$ and its tumor suppressor role has been observed in $\mathrm{MCPyV}-\mathrm{MCC}$ cell lines [41]. In MCPyV+ cell lines, we observed that suppression of miR-375 reduced cell growth and induced apoptosis, indicating that miR-375 is important to maintain cell viability in virus-positive cells. miR-375 is an MCC-specific miRNA and is highly expressed in MCPyV+ tumors and sera; it is thus not surprising that this miRNA plays pivotal roles in this tumor type.

Similar to MCC, miR-375 is also expressed in other neuroendocrine or endocrine organs, including pancreas [51,52], pituitary [53], adrenal [54], thyroid [55,56], lung [57], and gastrointestinal tract [58]. This miRNA has been demonstrated to play important roles in regulating cell differentiation [41,57-59], hormone synthesis, and secretion [51,52,54]. In cancer, $m i R-375$ is generally downregulated and functions as a suppressor of cell growth, invasion, and migration in multiple tumor types [60]. Additionally, miR-375 can regulate several cancer pathways, including Hippo, PI3K-Akt, Wnt, and Notch [60]. In MCPyV - MCC, it was demonstrated that miR-375 could repress multiple targets of the Notch signaling that lead to suppression of cell viability, migration, and invasion [41].

It has also been shown that miR-375 can directly repress the key glycolytic enzyme LDHB [39]. Given that MCPyV small T-antigen can promote glycolysis [61], we speculated that miR-375 regulation of LDHB might be important in MCC tumorigenesis. Here, we demonstrated that LDHB mRNA and protein levels were reduced following over-expression of miR-375 and increased after suppression of $m i R-375$, supporting that $L D H B$ is a target of miR-375 in MCC. Functionally, we showed that silencing of LDHB could phenocopy the anti-survival effect of miR-375 over-expression in MCPyV - MCC cell lines, indicating its oncogenic role. The results are consistent with previous studies supporting that LDHB promotes tumor development and progression [43]. However, in MCPyV+ MCC cell lines, silencing of LDHB could rescue the cell growth inhibition effect mediated by miR-375 suppression, suggesting its role as a suppressor in MCPyV+ MCC. Similarly, reduced LDHB expression levels have also been observed in several cancer types, such as prostate cancer [44] and pancreatic cancer [62]. One common observation between these tumor types and MCPyV small T-antigen-transfected cells is their glycolytic phenotype. One possible explanation for the differential role of LDHB in MCPyV+ and MCPyV - MCC cell lines is that MCPyV+ cell lines rely on aerobic glycolysis, which requires continuous generation of NAD+ from LDHB suppression, while the oxidative cancer cells largely rely on LDHB activity to generate substrates for the Krebs cycle that fuels cellular activities. It is thus tempting to speculate that cellular metabolisms in $\mathrm{MCPyV}+$ and MCPyV $-\mathrm{MCC}$ cells are different from one another; $\mathrm{MCPyV}+$ cells are likely glycolytic and $\mathrm{MCPyV}-$ cells are oxidative. Given that 
the MCPyV small T-antigen can promote a pro-glycolytic phenotype, the question arises whether the viral oncoprotein could change the cellular metabolism of the cells that converts LDHB from its oncogenic role to tumor suppressor. Alternatively, the differential roles observed could be due to different cellular contexts rather than an effect of the virus itself. Further investigations are warranted to fully understand cellular metabolism differences between these two groups and whether MCPyV oncoproteins could change cellular metabolism of the cells or the function of LDHB.

\section{Materials and Methods}

\subsection{Cell Lines}

Six MCC cell lines were included in this study. MCC13, MCC14/2, and MCC26 are MCPyVcell lines, which were purchased from CellBank Australia (Westmead, Australia). WaGa, MKL-1, and MKL-2 are MCPyV+ cell lines, which were kindly provided by Drs. Jürgen C. Becker (Medical University of Graz, Graz, Austria), Nancy L. Krett (Northwestern University, Chicago, IL, USA), and Roland Houben (University Hospital Würzburg, Würzburg, Germany), respectively. All MCC cells were grown in RPMI-1640 medium supplemented with 10\% (WaGa, MKL-1, and MKL-2) or 15\% (MCC13, MCC14/2, and MCC26) fetal bovine serum at $37{ }^{\circ} \mathrm{C}$ with $5 \% \mathrm{CO}_{2}$. The authenticity of the cell lines was verified by short tandem repeat (STR) profiling in our recent study [63].

\subsection{Tumor Samples}

Twenty-six formalin-fixed paraffin-embedded (FFPE) and 28 frozen tumor samples were collected from the Karolinska University Hospital and Stockholm South General Hospital (Stockholm, Sweden). All samples had been included in our previous studies $[18,63]$. The study was approved by the Ethics Committee of Karolinska Institutet (2010/1092-31/3), and the use of archival materials was approved by the Karolinska University Hospital Biobank (BbK-00557). All materials were coded. The materials were obtained with written informed consent, except those samples collected prior to 2010, which at that time were covered by a general application of endocrine tumor collection approved by the ethic committee board of the Karolinska Institutet (Dnr. 91:86), and oral informed consent was applied.

\subsection{RNA Extraction}

Total RNA was extracted using mirVana miRNA isolation kit (Applied Biosystem/Ambion, Austin, TX, USA) and the concentrations were measured with the NanoDrop ND-1000 spectrophotometer (NanoDrop Technologies, Wilmington, DE, USA) and stored at $-80{ }^{\circ} \mathrm{C}$ for further use.

\subsection{TaqMan Reverse Transcription-Quantitative PCR (RT-qPCR)}

Reverse transcription-quantitative polymerase chain reaction (RT-qPCR) was used to quantify miR-375 and LDHB expressions using the StepOnePlus ${ }^{\mathrm{TM}}$ Real-Time PCR system (Life Technologies, Carlsbad, CA, USA). Predesigned TaqMan assays for mature miR-375 (ID_000564), RNU6B (ID_001093), LDHB (Hs00929956_m1) and GAPDH (Hs99999905_m1) were purchased from Applied Biosystems. For mature miR-375 and RNU6B, cDNA was synthesized from 120 ng total RNAs using TaqMan MicroRNA Reverse Transcription Kit (cat. no. 4366597; Applied Biosystems). For mRNAs, 100 ng total RNAs was used for cDNA synthesis using High Capacity cDNA Reverse Transcription kit (cat. no. 4368814; Applied Biosystems). All reactions were performed in triplicate. The relative expression levels of mature miR-375 were normalized to $R N U 6 B$, while the $L D H B$ expressions were normalized to $G A P D H$. The quantification of $m i R-375$ and RNU6B in 26 samples was previously analyzed [18], while the remaining samples were analyzed in this study. 


\subsection{Transfection Experiments}

For over-expression of miR-375, $3 \times 10^{5}$ cells of MCC13, MCC14/2, and MCC26 were transfected with $10 \mathrm{nM}$ of mirVana miR-375 mimic (MC10327, Ambion) or mirVana miRNA mimic Negative Control\#1 (NC, AM17110; Ambion) using Lipofectamine ${ }^{\circledR}$ RNAiMAX Reagent (Invitrogen, Carlsbad, CA, USA) or $1.5 \mu \mathrm{g}$ of plasmid DNA (miR-375 OE or pcDNA3) using Lipofectamine 2000 (Invitrogen). Stable miR-375 OE-transfected cells were established by selection with G418 ( $1 \mathrm{mg} / \mathrm{mL}$; Invitrogen) for at least four weeks. For inhibition of $m i R-375,2 \mu \mathrm{g}$ of miR-375sp, or pcDNA3 plasmid DNA was transfected into $4 \times 10^{6} \mathrm{WaGa}$ and MKL-1 cells using the Amaxa Cell Line Nucleofector kit V (program D-24 and A-24, respectively; Lonza, Basel, Switzerland). miR-375 expression (miR-375 OE) and sponge (miR-375sp) vectors were generated in our previous studies [63].

Co-transfection of miR-375sp and siLDHB \#1 (100 nM; SI03032589, Qiagen, Hilden, Germany), siLDHB \#2 (100 nM; SI03052182, Qiagen) or control siRNA (100 nM; siCTR, SI03052182; Qiagen) were performed in $4 \times 10^{6}$ of WaGa and MKL-1 cells using the same nucleofection protocol. For silencing of LDHB in MCPyV - cell lines, $3 \times 10^{5}$ cells of MCC13, MCC14/2, and MCC26 were transfected with $10 \mathrm{nM}$ of siLDHB \#1, siLDHB \#2, or siCTR using Lipofectamine 2000.

\subsection{WST-1 Cell Viability Assay}

Cell proliferation was measured by using WST-1 (cat. no. 11644807001; Roche Applied Science, Mannheim, Germany) colorimetric assay. At different time points (24, 48, 72, or $96 \mathrm{~h}$ post-transfection), $10 \mu \mathrm{L}$ of WST-1 reagent was added and incubated for $3 \mathrm{~h}$ (MCC13, MCC14/2, and MCC26), $2 \mathrm{~h}$ (WaGa), or $4 \mathrm{~h}$ (MKL-1) at $37^{\circ} \mathrm{C}$. Absorbance was determined at wavelengths $450 \mathrm{~nm}$ (measurement) and $650 \mathrm{~nm}$ (reference) using a VERSA max microplate reader (Molecular Devices, Sunnyvale, CA, USA). Each experimental group consisted of five or eight replicates for each time point and repeated three times independently.

\subsection{Trypan Blue Exclusion Assay}

Cells were stained with $0.4 \%$ trypan blue stain (Invitrogen) and analyzed using the TC10 $10^{\mathrm{TM}}$ automated cell counter (Bio-Rad, Hercules, CA, USA). Total live cells in the miR-375 OE, miR-375sp, and siLDHB-transfected cells were compared to their respective controls.

\subsection{Cell Cycle Analysis}

At $72 \mathrm{~h}$ after transfection, $1 \times 10^{6}$ cells were washed with PBS and fixed in cold 50\% ethanol for 1 h. After washing with PBS and treating with RNase A (0.2 mg/mL; R6513, Sigma-Aldrich, St. Louis, MO, USA) for $1 \mathrm{~h}$ at $37^{\circ} \mathrm{C}$, the cells were then stained with $10 \mu \mathrm{L}$ propidium iodide $(1 \mathrm{mg} / \mathrm{mL} ; \mathrm{P} 4170$, Sigma-Aldrich) and kept on ice in the dark. Cell cycle analysis was performed using flow cytometry (Cytomics FC 500; Beckman Coulter, Brea, CA, USA) and FlowJo software version 7.6.2 (Tree Star Inc., Ashland, OR, USA). All experiments were performed independently in triplicate.

\subsection{Wound Healing Scratch Assay}

After $48 \mathrm{~h}$ of transfection, a scratch wound was made on the confluent monolayer cells of each treatment group and cultured in low serum (2\% FBS) medium. The scratch was imaged in real-time using IncuCyte S3 (Essen BioScience, Ann Arbor, MI, USA). Image J software version 1.43u (http:/ / rsbweb.nih.gov/ij/) was used to process all images for quantification purposes. The wound closure (cell migration) was calculated by fraction of wound at the given time to the wound area at $0 \mathrm{~h}$ and normalized to viable cell number of transfected cells plated in parallel. Three independent replicates were included in each experimental group. 


\subsection{Apoptosis Assays}

Cell apoptosis was evaluated in WaGa cells after $72 \mathrm{~h}$ of transfection with miR-375sp or pcDNA3 using Annexin V FITC Apoptosis kit (cat. no. 640905; BioLegend, San Diego, CA, USA) and Caspase-3 colorimetric assay (\#K106; BioVision, Mountain View, CA, USA). All experimental conditions were performed according to the manufacturer's instructions. The Annexin V and propidium iodide-stained cells were analyzed by NovoCyte flow cytometer (ACEA Biosciences, San Diego, CA, USA), and the caspase-3 cleavage products were measured at wavelength $405 \mathrm{~nm}$ using a VERSAmax microplate reader (Molecular Devices). All experiments were replicated three times independently.

\subsection{Western Blot Analysis}

Cells were harvested and lysed using NP-40 lysis buffer (FNN0021; Life Technologies), supplemented with $1 \mathrm{mM}$ of phenylmethanesulfonyl fluoride (PMSF, Sigma-Aldrich) and protease inhibitor (complete protease inhibitor cocktail; Roche Diagnostics $\mathrm{GmbH}$ ). Protein concentrations were measured using the Pierce ${ }^{\mathrm{TM}}$ BCA Protein assay kit (Thermo Fisher scientific, Inc., Waltham, MA, USA). Twenty-five micrograms protein lysate were run in 4-12\% NuPAGE SDS or 12\% Bis-Tris gels (Invitrogen) and transferred to nitrocellulose membranes. Western blot membranes were incubated with LDHB (1:1000; A7625; ABclonal, Woburn, MA, USA), PARP (1:1000; \#556362; BD Biosciences, Franklin Lakes, NJ, USA) and cleaved PARP (1:1000; ab32064; Abcam, Cambridge, UK) antibodies. GAPDH (1:10,000, sc-47724; Santa Cruz Biotechnology Inc., Santa Cruz, CA, USA or 1:5000, \#5174 Cell Signaling technology, Danvers, MA, USA) was used for normalization. Signals were detected by LAS-1000 Image Analyzer (Fujifilm, Tokyo, Japan) and quantified by Image Gauge version 4.0 (Fujifilm).

\subsection{Statistical Analysis}

All analyses were performed using IBM SPSS Statistics version 24.0 (IBM Corp., Armonk, NY, USA) or MS Office Excel 2007. Paired Student's $t$-test was performed to analyze transfection experiments. Spearman's rank order correlation was used to evaluate correlation between miR-375 and $L D H B$ expressions. All analyses were 2 -tailed, and $p$-values $<0.05$ were regarded as significant.

\section{Conclusions}

We demonstrate distinct functional roles of miR-375 and LDHB in MCPyV+ and MCPyV- MCCs. Targeting LDHB could be a novel therapy for MCC.

Author Contributions: Conceptualization, S.K., H.X., and W.-O.L.; methodology, S.K., H.X., P.S., and L.L.; validation, S.K., H.X., P.S., and L.L.; formal analysis, S.K., H.X., and P.S.; investigation, S.K., H.X., and P.S.; resources, V.B. and A.H.; data curation, S.K., H.X., and W.-O.L.; writing-original draft preparation, S.K. and H.X.; writing-review and editing, C.L. and W.-O.L.; visualization, S.K., H.X., P.S., and W.-O.L.; supervision, W.-O.L.; project administration, C.L. and W.-O.L.; and funding acquisition, C.L. and W.-O.L. All authors read and approved the final version of the manuscript.

Funding: This work was supported by the Swedish Cancer Society, Cancer Research Funds of Radiumhemmet, Karolinska Institutet, Stockholm County Council, National Natural Science Foundation of China (81773002) and the Natural Science Foundation of Tianjin (16JCYBJC42400). S.K. is supported by the Karolinska Institutet PhD program (KID).

Acknowledgments: We thank Jürgen C. Becker (Medical University of Graz, Graz, Austria), Nancy L. Krett (Northwestern University, Chicago, IL, USA), and Roland Houben (University Hospital Würzburg, Würzburg, Germany) for providing MCC cell lines. We also thank all members in the Medical Genetics research group for helpful discussions and suggestions.

Conflicts of Interest: The authors declare no competing interests.

\section{References}

1. Feng, H.; Shuda, M.; Chang, Y.; Moore, P.S. Clonal integration of a polyomavirus in human Merkel cell carcinoma. Science 2008, 319, 1096-1100. [CrossRef] [PubMed] 
2. Shuda, M.; Feng, H.; Kwun, H.J.; Rosen, S.T.; Gjoerup, O.; Moore, P.S.; Chang, Y. T antigen mutations are a human tumor-specific signature for Merkel cell polyomavirus. Proc. Natl. Acad. Sci. USA 2008, 105, 16272-16277. [CrossRef] [PubMed]

3. Borchert, S.; Czech-Sioli, M.; Neumann, F.; Schmidt, C.; Wimmer, P.; Dobner, T.; Grundhoff, A.; Fischer, N. High-affinity $\mathrm{Rb}$ binding, p53 inhibition, subcellular localization, and transformation by wild-type or tumor-derived shortened Merkel cell polyomavirus large T antigens. J. Virol. 2014, 88, 3144-3160. [CrossRef] [PubMed]

4. Houben, R.; Adam, C.; Baeurle, A.; Hesbacher, S.; Grimm, J.; Angermeyer, S.; Henzel, K.; Hauser, S.; Elling, R.; Brocker, E.B.; et al. An intact retinoblastoma protein-binding site in Merkel cell polyomavirus large T antigen is required for promoting growth of Merkel cell carcinoma cells. Int. J. Cancer 2012, 130, 847-856. [CrossRef] [PubMed]

5. Houben, R.; Shuda, M.; Weinkam, R.; Schrama, D.; Feng, H.; Chang, Y.; Moore, P.S.; Becker, J.C. Merkel cell polyomavirus-infected Merkel cell carcinoma cells require expression of viral T antigens. J. Virol. 2010, 84, 7064-7072. [CrossRef] [PubMed]

6. Knight, L.M.; Stakaityte, G.; Wood, J.J.; Abdul-Sada, H.; Griffiths, D.A.; Howell, G.J.; Wheat, R.; Blair, G.E.; Steven, N.M.; Macdonald, A.; et al. Merkel cell polyomavirus small T antigen mediates microtubule destabilization to promote cell motility and migration. J. Virol. 2015, 89, 35-47. [CrossRef] [PubMed]

7. Kwun, H.J.; Shuda, M.; Feng, H.; Camacho, C.J.; Moore, P.S.; Chang, Y. Merkel cell polyomavirus small $\mathrm{T}$ antigen controls viral replication and oncoprotein expression by targeting the cellular ubiquitin ligase SCFFbw7. Cell Host Microbe 2013, 14, 125-135. [CrossRef] [PubMed]

8. Kwun, H.J.; Wendzicki, J.A.; Shuda, Y.; Moore, P.S.; Chang, Y. Merkel cell polyomavirus small T antigen induces genome instability by E3 ubiquitin ligase targeting. Oncogene 2017, 36, 6838. [CrossRef] [PubMed]

9. Richards, K.F.; Guastafierro, A.; Shuda, M.; Toptan, T.; Moore, P.S.; Chang, Y. Merkel cell polyomavirus $\mathrm{T}$ antigens promote cell proliferation and inflammatory cytokine gene expression. J. Gen. Virol. 2015, 96, 3532-3544. [CrossRef] [PubMed]

10. Shuda, M.; Guastafierro, A.; Geng, X.; Shuda, Y.; Ostrowski, S.M.; Lukianov, S.; Jenkins, F.J.; Honda, K.; Maricich, S.M.; Moore, P.S.; et al. Merkel cell polyomavirus small T antigen induces cancer and embryonic Merkel cell proliferation in a transgenic mouse model. PLoS ONE 2015, 10, e0142329. [CrossRef] [PubMed]

11. Shuda, M.; Kwun, H.J.; Feng, H.; Chang, Y.; Moore, P.S. Human Merkel cell polyomavirus small T antigen is an oncoprotein targeting the 4E-BP1 translation regulator. J. Clin. Investig. 2011, 121, 3623-3634. [CrossRef] [PubMed]

12. Shuda, M.; Velasquez, C.; Cheng, E.; Cordek, D.G.; Kwun, H.J.; Chang, Y.; Moore, P.S. CDK1 substitutes for mTOR kinase to activate mitotic cap-dependent protein translation. Proc. Natl. Acad. Sci. USA 2015, 112, 5875-5882. [CrossRef] [PubMed]

13. Arora, R.; Shuda, M.; Guastafierro, A.; Feng, H.; Toptan, T.; Tolstov, Y.; Normolle, D.; Vollmer, L.L.; Vogt, A.; Domling, A.; et al. Survivin is a therapeutic target in Merkel cell carcinoma. Sci. Transl. Med. 2012, 4, 133 ra56. [CrossRef] [PubMed]

14. Bhatia, K.; Goedert, J.J.; Modali, R.; Preiss, L.; Ayers, L.W. Immunological detection of viral large T antigen identifies a subset of Merkel cell carcinoma tumors with higher viral abundance and better clinical outcome. Int. J. Cancer 2010, 127, 1493-1496. [CrossRef] [PubMed]

15. Harms, P.W.; Patel, R.M.; Verhaegen, M.E.; Giordano, T.J.; Nash, K.T.; Johnson, C.N.; Daignault, S.; Thomas, D.G.; Gudjonsson, J.E.; Elder, J.T.; et al. Distinct gene expression profiles of viral- and nonviral-associated Merkel cell carcinoma revealed by transcriptome analysis. J. Investig. Dermatol. 2013, 133, 936-945. [CrossRef] [PubMed]

16. Laude, H.C.; Jonchere, B.; Maubec, E.; Carlotti, A.; Marinho, E.; Couturaud, B.; Peter, M.; Sastre-Garau, X.; Avril, M.F.; Dupin, N.; et al. Distinct Merkel cell polyomavirus molecular features in tumour and non tumour specimens from patients with Merkel cell carcinoma. PLoS Pathog. 2010, 6, e1001076. [CrossRef] [PubMed]

17. Sihto, H.; Kukko, H.; Koljonen, V.; Sankila, R.; Bohling, T.; Joensuu, H. Clinical factors associated with Merkel cell polyomavirus infection in Merkel cell carcinoma. J. Natl. Cancer Inst. 2009, 101, 938-945. [CrossRef] [PubMed]

18. Xie, H.; Lee, L.; Caramuta, S.; Hoog, A.; Browaldh, N.; Bjornhagen, V.; Larsson, C.; Lui, W.O. MicroRNA expression patterns related to Merkel cell polyomavirus infection in human Merkel cell carcinoma. J. Investig. Dermatol. 2014, 134, 507-517. [CrossRef] [PubMed] 
19. Fan, K.; Ritter, C.; Nghiem, P.; Blom, A.; Verhaegen, M.E.; Dlugosz, A.; Ødum, N.; Woetmann, A.; Tothill, R.W.; Hicks, R.J.; et al. Circulating cell-free miR-375 as surrogate marker of tumor burden in Merkel cell carcinoma. Clin. Cancer Res. 2018. [CrossRef] [PubMed]

20. Renwick, N.; Cekan, P.; Masry, P.A.; McGeary, S.E.; Miller, J.B.; Hafner, M.; Li, Z.; Mihailovic, A.; Morozov, P.; Brown, M.; et al. Multicolor microRNA FISH effectively differentiates tumor types. J. Clin. Investig. 2013, 123, 2694-2702. [CrossRef] [PubMed]

21. Ding, L.; Xu, Y.; Zhang, W.; Deng, Y.; Si, M.; Du, Y.; Yao, H.; Liu, X.; Ke, Y.; Si, J.; et al. MiR-375 frequently downregulated in gastric cancer inhibits cell proliferation by targeting JAK2. Cell Res. 2010, 20, 784-793. [CrossRef] [PubMed]

22. Tsukamoto, Y.; Nakada, C.; Noguchi, T.; Tanigawa, M.; Nguyen, L.T.; Uchida, T.; Hijiya, N.; Matsuura, K.; Fujioka, T.; Seto, M.; et al. MicroRNA-375 is downregulated in gastric carcinomas and regulates cell survival by targeting PDK1 and 14-3-3zeta. Cancer Res. 2010, 70, 2339-2349. [CrossRef] [PubMed]

23. Chang, C.; Shi, H.; Wang, C.; Wang, J.; Geng, N.; Jiang, X.; Wang, X. Correlation of microRNA-375 downregulation with unfavorable clinical outcome of patients with glioma. Neurosci. Lett. 2012, 531, $204-208$. [CrossRef] [PubMed]

24. Dai, X.; Chiang, Y.; Wang, Z.; Song, Y.; Lu, C.; Gao, P.; Xu, H. Expression levels of microRNA-375 in colorectal carcinoma. Mol Med Rep 2012, 5, 1299-1304. [CrossRef] [PubMed]

25. Faltejskova, P.; Svoboda, M.; Srutova, K.; Mlcochova, J.; Besse, A.; Nekvindova, J.; Radova, L.; Fabian, P.; Slaba, K.; Kiss, I.; et al. Identification and functional screening of microRNAs highly deregulated in colorectal cancer. J. Cell. Mol. Med. 2012, 16, 2655-2666. [CrossRef] [PubMed]

26. Harris, T.; Jimenez, L.; Kawachi, N.; Fan, J.B.; Chen, J.; Belbin, T.; Ramnauth, A.; Loudig, O.; Keller, C.E.; Smith, R.; et al. Low-level expression of miR-375 correlates with poor outcome and metastasis while altering the invasive properties of head and neck squamous cell carcinomas. Am. J. Pathol. 2012, 180, 917-928. [CrossRef] [PubMed]

27. Zhou, J.; Song, S.; Cen, J.; Zhu, D.; Li, D.; Zhang, Z. MicroRNA-375 is downregulated in pancreatic cancer and inhibits cell proliferation in vitro. Oncol. Res. 2012, 20, 197-203. [CrossRef] [PubMed]

28. He, X.X.; Chang, Y.; Meng, F.Y.; Wang, M.Y.; Xie, Q.H.; Tang, F.; Li, P.Y.; Song, Y.H.; Lin, J.S. MicroRNA-375 targets AEG-1 in hepatocellular carcinoma and suppresses liver cancer cell growth in vitro and in vivo. Oncogene 2012, 31, 3357-3369. [CrossRef] [PubMed]

29. Wang, F.; Li, Y.; Zhou, J.; Xu, J.; Peng, C.; Ye, F.; Shen, Y.; Lu, W.; Wan, X.; Xie, X. miR-375 is down-regulated in squamous cervical cancer and inhibits cell migration and invasion via targeting transcription factor SP1. Am. J. Pathol. 2011, 179, 2580-2588. [CrossRef] [PubMed]

30. Hudson, J.; Duncavage, E.; Tamburrino, A.; Salerno, P.; Xi, L.; Raffeld, M.; Moley, J.; Chernock, R.D. Overexpression of miR-10a and miR-375 and downregulation of YAP1 in medullary thyroid carcinoma. Exp. Mol. Pathol. 2013, 95, 62-67. [CrossRef] [PubMed]

31. De Souza Rocha Simonini, P.; Breiling, A.; Gupta, N.; Malekpour, M.; Youns, M.; Omranipour, R.; Malekpour, F.; Volinia, S.; Croce, C.M.; Najmabadi, H.; et al. Epigenetically deregulated microRNA-375 is involved in a positive feedback loop with estrogen receptor alpha in breast cancer cells. Cancer Res. 2010, 70, 9175-9184. [CrossRef] [PubMed]

32. Szczyrba, J.; Nolte, E.; Wach, S.; Kremmer, E.; Stohr, R.; Hartmann, A.; Wieland, W.; Wullich, B.; Grasser, F.A. Downregulation of Sec23A protein by miRNA-375 in prostate carcinoma. Mol. Cancer Res. 2011, 9, 791-800. [CrossRef] [PubMed]

33. Kong, K.L.; Kwong, D.L.; Chan, T.H.; Law, S.Y.; Chen, L.; Li, Y.; Qin, Y.R.; Guan, X.Y. MicroRNA-375 inhibits tumour growth and metastasis in oesophageal squamous cell carcinoma through repressing insulin-like growth factor 1 receptor. Gut 2012, 61, 33-42. [CrossRef] [PubMed]

34. Li, X.; Lin, R.; Li, J. Epigenetic silencing of microRNA-375 regulates PDK1 expression in esophageal cancer. Dig. Dis. Sci. 2011, 56, 2849-2856. [CrossRef] [PubMed]

35. Nishimura, Y.; Komatsu, S.; Ichikawa, D.; Nagata, H.; Hirajima, S.; Takeshita, H.; Kawaguchi, T.; Arita, T.; Konishi, H.; Kashimoto, K.; et al. Overexpression of YWHAZ relates to tumor cell proliferation and malignant outcome of gastric carcinoma. Br. J. Cancer 2013, 108, 1324-1331. [CrossRef] [PubMed]

36. Liu, A.M.; Poon, R.T.; Luk, J.M. MicroRNA-375 targets Hippo-signaling effector YAP in liver cancer and inhibits tumor properties. Biochem. Biophys. Res. Commun. 2010, 394, 623-627. [CrossRef] [PubMed] 
37. Nohata, N.; Hanazawa, T.; Kikkawa, N.; Mutallip, M.; Sakurai, D.; Fujimura, L.; Kawakami, K.; Chiyomaru, T.; Yoshino, H.; Enokida, H.; et al. Tumor suppressive microRNA-375 regulates oncogene AEG-1/MTDH in head and neck squamous cell carcinoma (HNSCC). J. Hum. Genet. 2011, 56, 595-601. [CrossRef] [PubMed]

38. Hui, A.B.; Bruce, J.P.; Alajez, N.M.; Shi, W.; Yue, S.; Perez-Ordonez, B.; Xu, W.; O'Sullivan, B.; Waldron, J.; Cummings, B.; et al. Significance of dysregulated metadherin and microRNA-375 in head and neck cancer. Clin. Cancer Res. 2011, 17, 7539-7550. [CrossRef] [PubMed]

39. Kinoshita, T.; Nohata, N.; Yoshino, H.; Hanazawa, T.; Kikkawa, N.; Fujimura, L.; Chiyomaru, T.; Kawakami, K.; Enokida, H.; Nakagawa, M.; et al. Tumor suppressive microRNA-375 regulates lactate dehydrogenase B in maxillary sinus squamous cell carcinoma. Int. J. Oncol. 2012, 40, 185-193. [CrossRef] [PubMed]

40. Hart, M.; Nolte, E.; Wach, S.; Szczyrba, J.; Taubert, H.; Rau, T.T.; Hartmann, A.; Grasser, F.A.; Wullich, B. Comparative microRNA profiling of prostate carcinomas with increasing tumor stage by deep sequencing. Mol. Cancer Res. 2014, 12, 250-263. [CrossRef] [PubMed]

41. Abraham, K.J.; Zhang, X.; Vidal, R.; Pare, G.C.; Feilotter, H.E.; Tron, V.A. Roles for miR-375 in neuroendocrine differentiation and tumor suppression via Notch pathway suppression in Merkel cell carcinoma. Am. J. Pathol. 2016, 186, 1025-1035. [CrossRef] [PubMed]

42. Shao, Q.; Byrum, S.D.; Moreland, L.E.; Mackintosh, S.G.; Kannan, A.; Lin, Z.; Morgan, M.; Stack, B.C., Jr.; Cornelius, L.A.; Tackett, A.J.; et al. A proteomic study of human Merkel cell carcinoma. J. Proteomics Bioinform. 2013, 6, 275-282. [CrossRef] [PubMed]

43. Brisson, L.; Banski, P.; Sboarina, M.; Dethier, C.; Danhier, P.; Fontenille, M.J.; Van Hee, V.F.; Vazeille, T.; Tardy, M.; Falces, J.; et al. Lactate Dehydrogenase B controls lysosome activity and autophagy in cancer. Cancer Cell 2016, 30, 418-431. [CrossRef] [PubMed]

44. Liu, J.; Chen, G.; Liu, Z.; Liu, S.; Cai, Z.; You, P.; Ke, Y.; Lai, L.; Huang, Y.; Gao, H.; et al. Aberrant FGFR tyrosine kinase signaling enhances the Warburg effect by reprogramming LDH isoform expression and activity in prostate cancer. Cancer Res. 2018, 78, 4459-4470. [CrossRef] [PubMed]

45. McCleland, M.L.; Adler, A.S.; Shang, Y.; Hunsaker, T.; Truong, T.; Peterson, D.; Torres, E.; Li, L.; Haley, B.; Stephan, J.P.; et al. An integrated genomic screen identifies LDHB as an essential gene for triple-negative breast cancer. Cancer Res. 2012, 72, 5812-5823. [CrossRef] [PubMed]

46. Garneski, K.M.; Warcola, A.H.; Feng, Q.; Kiviat, N.B.; Leonard, J.H.; Nghiem, P. Merkel cell polyomavirus is more frequently present in North American than Australian Merkel cell carcinoma tumors. J. Investig. Dermatol. 2009, 129, 246-248. [CrossRef] [PubMed]

47. Moshiri, A.S.; Doumani, R.; Yelistratova, L.; Blom, A.; Lachance, K.; Shinohara, M.M.; Delaney, M.; Chang, O.; McArdle, S.; Thomas, H.; et al. Polyomavirus-negative Merkel cell carcinoma: A more aggressive subtype based on analysis of 282 cases using multimodal tumor virus detection. J. Investig. Dermatol. 2017, 137, 819-827. [CrossRef] [PubMed]

48. Wong, S.Q.; Waldeck, K.; Vergara, I.A.; Schroder, J.; Madore, J.; Wilmott, J.S.; Colebatch, A.J.; De Paoli-Iseppi, R.; Li, J.; Lupat, R.; et al. UV-associated mutations underlie the etiology of MCV-negative Merkel cell carcinomas. Cancer Res. 2015, 75, 5228-5234. [CrossRef] [PubMed]

49. Starrett, G.J.; Marcelus, C.; Cantalupo, P.G.; Katz, J.P.; Cheng, J.; Akagi, K.; Thakuria, M.; Rabinowits, G.; Wang, L.C.; Symer, D.E.; et al. Merkel cell polyomavirus exhibits dominant control of the tumor genome and transcriptome in virus-associated Merkel cell carcinoma. MBio 2017, 8. [CrossRef] [PubMed]

50. Sunshine, J.C.; Jahchan, N.S.; Sage, J. Are there multiple cells of origin of Merkel cell carcinoma? Oncogene 2018, 37, 1409-1416. [CrossRef] [PubMed]

51. El Ouaamari, A.; Baroukh, N.; Martens, G.A.; Lebrun, P.; Pipeleers, D.; van Obberghen, E. miR-375 targets 3'-phosphoinositide-dependent protein kinase-1 and regulates glucose-induced biological responses in pancreatic beta-cells. Diabetes 2008, 57, 2708-2717. [CrossRef] [PubMed]

52. Poy, M.N.; Eliasson, L.; Krutzfeldt, J.; Kuwajima, S.; Ma, X.; Macdonald, P.E.; Pfeffer, S.; Tuschl, T.; Rajewsky, N.; Rorsman, P.; et al. A pancreatic islet-specific microRNA regulates insulin secretion. Oncogene 2004, 432, 226-230. [CrossRef] [PubMed]

53. Zhang, N.; Lin, J.K.; Chen, J.; Liu, X.F.; Liu, J.L.; Luo, H.S.; Li, Y.Q.; Cui, S. MicroRNA 375 mediates the signaling pathway of corticotropin-releasing factor (CRF) regulating pro-opiomelanocortin (POMC) expression by targeting mitogen-activated protein kinase 8. J. Biol. Chem. 2013, 288, 10361-10373. [CrossRef] [PubMed] 
54. Gai, Y.; Zhang, J.; Wei, C.; Cao, W.; Cui, Y.; Cui, S. miR-375 negatively regulates the synthesis and secretion of catecholamines by targeting Sp1 in rat adrenal medulla. Am. J. Physiol. Cell. Physiol. 2017, 312, C663-C672. [CrossRef] [PubMed]

55. Dettmer, M.; Perren, A.; Moch, H.; Komminoth, P.; Nikiforov, Y.E.; Nikiforova, M.N. Comprehensive microRNA expression profiling identifies novel markers in follicular variant of papillary thyroid carcinoma. Thyroid 2013, 23, 1383-1389. [CrossRef] [PubMed]

56. Mian, C.; Pennelli, G.; Fassan, M.; Balistreri, M.; Barollo, S.; Cavedon, E.; Galuppini, F.; Pizzi, M.; Vianello, F.; Pelizzo, M.R.; et al. MicroRNA profiles in familial and sporadic medullary thyroid carcinoma: Preliminary relationships with RET status and outcome. Thyroid 2012, 22, 890-896. [CrossRef] [PubMed]

57. Nishikawa, E.; Osada, H.; Okazaki, Y.; Arima, C.; Tomida, S.; Tatematsu, Y.; Taguchi, A.; Shimada, Y.; Yanagisawa, K.; Yatabe, Y.; et al. miR-375 is activated by ASH1 and inhibits YAP1 in a lineage-dependent manner in lung cancer. Cancer Res. 2011, 71, 6165-6173. [CrossRef] [PubMed]

58. Knudsen, L.A.; Petersen, N.; Schwartz, T.W.; Egerod, K.L. The microRNA repertoire in enteroendocrine cells: Identification of miR-375 as a potential regulator of the enteroendocrine lineage. Endocrinology 2015, 156, 3971-3983. [CrossRef] [PubMed]

59. Biton, M.; Levin, A.; Slyper, M.; Alkalay, I.; Horwitz, E.; Mor, H.; Kredo-Russo, S.; Avnit-Sagi, T.; Cojocaru, G.; Zreik, F.; et al. Epithelial microRNAs regulate gut mucosal immunity via epithelium-T cell crosstalk. Nat. Immunol. 2011, 12, 239-246. [CrossRef] [PubMed]

60. Yan, J.W.; Lin, J.S.; He, X.X. The emerging role of miR-375 in cancer. Int. J. Cancer 2014, 135, 1011-1018. [CrossRef] [PubMed]

61. Berrios, C.; Padi, M.; Keibler, M.A.; Park, D.E.; Molla, V.; Cheng, J.; Lee, S.M. Merkel cell polyomavirus small T-antigen promotes pro-glycolytic metabolic perturbations required for transformation. PLoS Pathog. 2016, 12, e1006020. [CrossRef] [PubMed]

62. Cui, J.; Quan, M.; Jiang, W.; Hu, H.; Jiao, F.; Li, N.; Jin, Z.; Wang, L.; Wang, Y.; Wang, L. Suppressed expression of LDHB promotes pancreatic cancer progression via inducing glycolytic phenotype. Med. Oncol. 2015, 32, 143. [CrossRef] [PubMed]

63. Kumar, S.; Xie, H.; Shi, H.; Gao, J.; Juhlin, C.C.; Björnhagen, V.; Höög, A.; Lee, L.; Larsson, C.; Lui, W.-O. Merkel cell polyomavirus T-antigens induce microRNAs that suppress multiple autophagy genes. Int. J. Cancer 2018, under review. 